\title{
Monitoring studies should consider temporal variability to reveal relations between cyanobacterial abundance and environmental variables
}

\author{
JULIANA WOJCIECHOWSKI and ANDRÉ A. PADIAL
}

Universidade Federal do Paraná, Setor de Ciências Biológicas, Departamento de Botânica. Av. Cel. Francisco H. dos Santos, s/n, Jd. das Américas, Caixa Postal 19031, 80060-000 Curitiba, PR, Brasil

Manuscript received on August 13, 2014; accepted for publication on December 18, 2014

\begin{abstract}
One of the main goals of monitoring cyanobacteria blooms in aquatic environments is to reveal the relationship between cyanobacterial abundance and environmental variables. Studies typically correlate data that were simultaneously sampled. However, samplings occur sparsely over time and may not reveal the short-term responses of cyanobacterial abundance to environmental changes. In this study, we tested the hypothesis that stronger cyanobacteria $\mathrm{x}$ environment relationships in monitoring are found when the temporal variability of sampling points is incorporated in the statistical analyses. To this end, we investigated relationships between cyanobacteria and seven environmental variables that were sampled twice yearly for three years across 11 reservoirs, and data from an intensive monitoring in one of these reservoirs. Poor correlations were obtained when correlating data simultaneously sampled. In fact, the 'highly recurrent' role of phosphorus in cyanobacteria blooms is not properly observed in all sampling periods. On the other hand, the strongest correlation values for the total phosphorus $\mathrm{x}$ cyanobacteria relationship were observed when we used the variation of sampling points. We have also shown that environment variables better explain cyanobacteria when a time lag is considered. We conclude that, in cyanobacteria monitoring, the best approach to reveal determinants of cyanobacteria blooms is to consider environmental variability.
\end{abstract}

Key words: Harmful algae, reservoir, management, limnological variables, temporal variation, Neotropics.

\section{INTRODUCTION}

It is well established that increasing temperatures and nutrient concentrations in aquatic habitats are causing cyanobacterial blooms (Paerl and Huisman 2008, 2009). For this reason, cyanobacterial toxin release in freshwater is a major environmental issue, causing serious concern for sanitation companies (Chorus and Bartram 1999). In fact, cyanotoxins may cause

Correspondence to: Juliana Wojciechowski

E-mail: julianawoj@gmail.com the death of wildlife, affect livestock and result in negative effects to human health (Yoo et al. 1995, Azevedo et al. 2002).

Stability of the water column (Huszar et al. 2000, Dantas et al. 2011), high nutrient concentrations (mainly nitrogen and phosphorus) (Bouvy et al. 2000), high temperature (Paerl and Huisman 2008, 2009), and high luminosity (Chorus and Bartram 1999, Huszar et al. 2000) are the main factors that promote cyanobacterial blooms. Such evidence for the causes of cyanobacterial growth 
has been identified mainly in experiments (Paerl et al. 1985, Coles and Jones 2000, Aubriot and Bonilla 2012). Observational studies have also tried to relate environmental variables and cyanobacteria densities (Havens et al. 1998, Burford et al. 2007, Gomes et al. 2012). However, relationships between cyanobacteria densities or cyanotoxin concentrations with the variables described above are not always evident (Wicks and Thiel 1990, Quesada and Fernández-Valiente 1996, Vezie et al. 1998).

Observational studies are based mainly on simultaneous samplings of cyanobacterial abundance and environmental variables (e.g. Dantas et al. 2011, Moura et al. 2011, Bittencourt-Oliveira et al. 2012). The implicit assumption in these studies is that snapshot samples in a certain sampling location are a good representation of the environmental conditions in this location in comparison to other locations. This assumption can be met if samplings occur continuously over time, given that cyanobacteria respond to short-term environmental variations. Another issue that can affect relationships between cyanobacteria and environmental variables is the fact that cyanobacteria comprise species that may respond differently to the environmental variations. For instance, picocyanobacteria and large cyanobacterial colonies fundamentally have different ecological restrictions (Huisman et al. 2005). The presence of heterocyst, which determines Nitrogen fixation, is observed in only some cyanobacteria (Chorus and Bartram 1999). However, cyanobacteria monitoring by legal agencies evaluate cyanobacteria as one biological group.

Moreover, cyanobacteria monitoring usually carries out simultaneous and long-term periodic samplings (LTPS) of cyanobacteria and environmental variables. For instance, the Environmental Institute of the state of Paraná (Brazil) carries out samplings of cyanobacterial abundance and environmental variables, only twice a year in reservoirs for water supply and hydroelectricity generation, with the main goal of monitoring cyanobacteria blooms and environmental variations (IAP 2009). Periodic samplings may not reveal the cyanobacterial responses to environmental variables, and correlating such data may not be the best strategy to investigate relationships between cyanobacteria and environmental variables. We argue this given that cyanobacteria may respond rapidly to environmental variations.

A better alternative for LTPS may be to represent how environmental variables vary over time across sampling points. To our knowledge, there have been no studies relating environmental and cyanobacterial variability. Here, we aimed to investigate the relationship between cyanobacteria and environmental variables, with the hypothesis that stronger relationships are found when the variability of sampling points is used as the sampling unit in statistical analyses, instead of raw long-term periodic sampling values. We dug further into the reasons why LTPS may not be a good strategy to correlate cyanobacterial abundance and environmental variables by investigating correlations with environmental variables sampled at the same time, and sampled days before cyanobacterial survey.

\section{MATERIALS AND METHODS}

We investigated the relationship between cyanobacteria and environmental variables using data sampled in 11 reservoirs that are used for water supply and hydroelectricity generation in the state of Paraná, Brazil (Table I). These reservoirs vary on the level of degradation (Andreoli and Carneiro 2005), resulting in persistent toxic cyanobacterial blooms in "Irai" and "Alagados" reservoirs (Fernandes et al. 2005, 2011, IAP 2009). Data were provided by the program "Monitoring of water quality in the reservoirs of the state of Paraná" coordinated by the Paraná State Environmental Institute (IAP 2009) and by "SANEPAR" (The Sanitation Company of the state of Paraná, Brazil). Samples in the 11 reservoirs were taken approximately twice a year (such as in 
LTPS) between 2005 and 2008 (hereafter referred to as "IAP sampling"). In 2008, some reservoirs were not sampled twice, so the number of samplings vary by reservoir (Table I). In addition, the "Alagados" reservoir was monitored from 2008 to 2014 in a higher frequency than the other reservoirs, when cyanobacterial abundance reached 20,000 cell. $\mathrm{ml}^{-1}$ (hereafter referred to as "Alagados sampling"). In this reservoir, environmental variables were measured once a month and cyanobacteria was sampled weekly.

TABLE I

Geographic location of reservoirs and number of samples taken in each reservoir from 2005 to 2008.

\begin{tabular}{cccc}
\hline Reservoir & Latitude & Longitude & $\begin{array}{c}\text { Number of } \\
\text { samples }\end{array}$ \\
\hline Alagados & $25^{\circ} 01^{\prime} 05^{\prime \prime} \mathrm{S}$ & $50^{\circ} 03^{\prime} 39^{\prime \prime} \mathrm{W}$ & 7 \\
Capivari & $25^{\circ} 08^{\prime} 31^{\prime \prime} \mathrm{S}$ & $48^{\circ} 51^{\prime} 60^{\prime \prime} \mathrm{W}$ & 7 \\
Guaricana & $25^{\circ} 43^{\prime} 35^{\prime \prime} \mathrm{S}$ & $48^{\circ} 56^{\prime} 57^{\prime \prime} \mathrm{W}$ & 6 \\
Iraí & $25^{\circ} 25^{\prime} 31^{\prime \prime} \mathrm{S}$ & $49^{\circ} 07^{\prime} 07^{\prime \prime} \mathrm{W}$ & 9 \\
Itaipu & $25^{\circ} 24^{\prime} 26^{\prime \prime} \mathrm{S}$ & $54^{\circ} 34^{\prime} 44^{\prime \prime} \mathrm{W}$ & 7 \\
Passaúna & $25^{\circ} 31^{\prime} 45^{\prime \prime} \mathrm{S}$ & $49^{\circ} 23^{\prime} 30^{\prime \prime} \mathrm{W}$ & 7 \\
Piraquara I & $25^{\circ} 30^{\prime} 17^{\prime \prime} \mathrm{S}$ & $49^{\circ} 01^{\prime} 40^{\prime \prime} \mathrm{W}$ & 8 \\
Rio Verde & $25^{\circ} 31^{\prime} 41^{\prime \prime} \mathrm{S}$ & $49^{\circ} 31^{\prime} 39^{\prime \prime} \mathrm{W}$ & 7 \\
Salto Caxias & $25^{\circ} 32^{\prime} 34^{\prime \prime} \mathrm{S}$ & $53^{\circ} 29^{\prime} 40^{\prime \prime} \mathrm{W}$ & 7 \\
Salto Santiago & $25^{\circ} 37^{\prime} 39^{\prime \prime} \mathrm{S}$ & $52^{\circ} 36^{\prime} 32^{\prime \prime} \mathrm{W}$ & 7 \\
Vossoroca & $25^{\circ} 49^{\prime} 05^{\prime \prime} \mathrm{S}$ & $49^{\circ} 05^{\prime} 11^{\prime \prime} \mathrm{W}$ & 7 \\
\hline
\end{tabular}

Samples of both cyanobacterial abundance (cells. $\mathrm{mL}^{-1}$ ) and environmental variables were taken in the sub-surface, in the lacustrine portion of the reservoirs. The environmental variables sampled for IAP sampling were: ammonium $\left(\mathrm{NH}_{4}{ }^{+}, \mathrm{mg} . \mathrm{L}^{-1}\right)$, chemical oxygen demand (COD, mg. $\mathrm{L}^{-1}$ ), dissolved oxygen (DO, \%), nitrate $\left(\mathrm{NO}_{3}^{-}, \mathrm{mg} . \mathrm{L}^{-1}\right)$, nitrite $\left(\mathrm{NO}_{2}{ }^{2-}, \mathrm{mg} . \mathrm{L}^{-1}\right)$, transparency ( $\mathrm{m}$, using Secchi disk depth), and total phosphorus (TP, mg. $\left.\mathrm{L}^{-1}\right)$.

For Alagados, the sampled environmental variables were: water column depth $(\mathrm{m})$, water temperature $\left({ }^{\circ} \mathrm{C}\right), \mathrm{pH}$, dissolved oxygen (DO, mg. $\left.\mathrm{L}^{-1}\right)$, ammonium $\left(\mathrm{NH}_{4}^{+}, \mathrm{mg} . \mathrm{L}^{-1}\right)$, nitrate $\left(\mathrm{NO}_{3}^{-}\right.$, mg. $\left.\mathrm{L}^{-1}\right)$, nitrite $\left(\mathrm{NO}_{2}{ }^{2-}, \mathrm{mg} . \mathrm{L}^{-1}\right)$, total phosphorus (TP, mg. $\mathrm{L}^{-1}$ ), soluble reactive phosphorus (SRP, $\left.\mathrm{mg} . \mathrm{L}^{-1}\right)$, turbidity (NTU), conductivity $(\mu \mathrm{S}$. $\mathrm{cm}^{-1}$ ), chemical oxygen demand (COD, mg. $\mathrm{L}^{-1}$ ) and biochemical oxygen demand (BOD, mg. $\mathrm{L}^{-1}$ ).
We used three approaches to correlate environmental variables and abundance of cyanobacteria in IAP sampling. First, we used data from simultaneous samplings of cyanobacteria and environmental variables, hereafter referred to as the simultaneous approach (SA). As for the approaches described below, the reservoir was used as the sampling unit in correlation analyses $(\mathrm{N}=11)$. Given that we have several sampling periods for each reservoir (up to nine, see Table I), we calculated SA correlations for each sampling period in which all reservoirs were sampled (six samples during summer and winter from 2005 to 2008, Table I). Then we considered the mean correlation across all these temporal samples as the estimate of the relationship between cyanobacteria and environmental variables when they were simultaneously sampled.

Second, we used the temporal average of variables for each reservoir as values in the correlation analyses $(\mathrm{N}=11)$, hereafter called the mean approach (MA). We believe that the mean value of each reservoir over sampling periods is a better representation of how the habitat in one location compares to another, and possibly how environmental processes explain cyanobacterial abundance. It could also be understood as a metric that captures the temporal variability of the reservoir as it relates the mean values over a time spam.

Third, we used the temporal variance of environmental variables and cyanobacterial abundance for each reservoir in the correlation analyses $(\mathrm{N}=$ 11), hereafter referred to as the variability approach (VA). We used this metric to represent how each sampling point varies over time. The interpretation of correlations in VA is different from SA and MA: a strong correlation in VA means that reservoirs with high environmental variations also have high variations in cyanobacterial abundance. In this case, a possible prediction is related to the cyanobacterial variability (not to the amount of cyanobacteria) explained by the variability of ecological processes. In SA and MA, in contrast, a strong correlation 
means that reservoirs with high values of a certain environmental variable also have high values of cyanobacterial abundance. We used variance in VA instead of other measures of dispersion because our goal was to represent overall dispersion and not a dispersion measure that is relative to the mean value (e.g. coefficient of variation).

We hypothesized that MA and VA would result in stronger cyanobacteria-environment correlations when compared to SA. Correlations generated by these three approaches can be compared by considering the magnitude of the coefficient. Usually, studies focus on significance values to evaluate if there is or there is not, an association between environmental data and cyanobacteria (e.g. Oliveira et al. 2014). It is clear that significance depends on the sampling effort (McBride 2005), and thus we used the same number of sampling units (i.e. 11 reservoirs) for all approaches. However, the significance of each relationship is not important here, since our goal is to reveal the stronger cyanobacteria-environment correlations, and not the significant ones.

In addition to not representing the ecological process affecting cyanobacteria, since algae may respond to previous environmental variation, the rationale of proposing $\mathrm{MA}$ and $\mathrm{VA}$ as an alternative for SA was also to unravel a common misinterpretation regarding ecological data. Absolute values of both environmental variables and cyanobacterial abundance vary over time in most ecosystems (Dantas et al. 2011, Gomes et al. 2012), highlighting the importance of temporally structured ecological processes. However, it is unclear how environmental determinism on cyanobacteria varies. If SA correlations have a large variation - for instance, in some sampling periods the correlation is strong, and in others, the correlation is weak - it also indicates that simultaneous sampling and correlating environmental variables and cyanobacteria is not a suitable approach, so conclusions will be uncertain. Even though the values of MA or VA correlations may be within the range of variation of SA correlations, these approaches indicate that the variability of environmental and cyanobacterial data are related. We argue that if the MA and VA correlations are higher than the mean SA correlations, then the real effect of environmental variables on cyanobacteria should consider the temporal variation of raw data, and not the variation of correlations.

We used both Pearson and Spearman correlations in order to identify whether one was better than the other for each approach used (SA, MA or VA). A higher Pearson correlation indicates linear relationships, and higher Spearman correlation may suggest non-linear relationships between cyanobacterial abundance and environmental variables. We believe that there are other methods to relate cyanobacteria and environmental variables, however, our goal was to compare correlation coefficients commonly used to associate cyanobacteria and environmental variables, but only to compare strategies of finding predictors of cyanobacteria (i.e. the approaches described above).

In the Alagados reservoir, cyanobacterial samplings made by the SANEPAR Company were intensive. Cyanobacterial abundance was available not only for the same sampling periods of environmental variables sampling, but also for one week after environmental variable sampling. Therefore, we correlated environmental variables with cyanobacterial abundance sampled simultaneously ( $\mathrm{N}=38$ sampling periods spread from 2008 to 2014) and the same environmental variables with cyanobacteria sampled after c. one week ("time lag correlations"; $\mathrm{N}=36$ sampling periods spread from 2008 to 2014) in the Alagados reservoir. The rationale is that "time lag correlations" will be higher than simultaneous correlations, given that algae may respond to a previous environmental condition of the ecosystem. We used as response variables: both, total cyanobacteria abundance and the abundance of the most abundant taxa in blooms (in this case, 
Aphanizomenon sp., Cylindrospermopsis sp., and Dolichospermum sp.). All analyses were done in the software STATISTICA 7.1 (StatSoft 2005).

\section{RESULTS}

IAP SAMPLING

MA was the approach that resulted in the highest correlations between cyanobacterial abundance and environmental variables ( 5 out of 7 for Pearson; and 4 out of 7 for Spearman) (Table II). As expected, SA was the worst approach, having the highest correlation values only for 1 out of 7 environmental variables for both Pearson and Spearman correlations (Table II; SA and MA had the highest, and similar correlations considering Nitrate).

COD showed the strongest Pearson correlation with cyanobacterial abundance in SA $(r=0.65$; Table II). This was the only SA Pearson correlation that was stronger than MA or VA (Table II). For Spearman correlations, SA showed the strongest correlation for ammonium, although its absolute value could be considered weak ( $\rho=0.13$; Table II). On the other hand, correlation values were higher in MA than in SA for almost all variables (except ammonium, Table II). The highest Pearson correlations in MA were for total phosphorus and dissolved oxygen; and the highest Spearman correlations were for nitrate, transparency and COD. Correlations in VA were, in general, also higher than in SA (Table II). In VA, strong coefficients were found between cyanobacterial abundance and dissolved oxygen and total phosphorus by Pearson correlation; and nitrate, nitrite, and transparency by Spearman correlation (Table II).

We used the mean SA correlation over sampling periods to represent the correlation according to this approach. In this case, strong correlations were found in some sampling periods (e.g. $r=0.94$ for the Pearson correlation with COD), whereas extremely low values were recorded for other sampling periods - nearly 0 for the Pearson correlation with phosphorus and Spearman correlation with ammonium (see Table II). Relatedly, although strong phosphoruscyanobacteria relationships can be found in SA for some sampling periods (maximum values: $r=0.77$ or $\rho=0.51$, Table III), weak relationships can also be found (minimum values: $r=0.05$ or $\rho=0.22$, Table III), resulting in a low mean correlation. On the other hand, strong correlations were found for almost all variables (including for total phosphorus) when MA was used. For VA, a strong Pearson correlation between total phosphorus and cyanobacteria abundance was also evident.

\section{TABLE II}

Pearson $(r)$ and Spearman $(\rho)$ correlation coefficients between environmental variables and cyanobacterial density (cells $\mathrm{mL}^{-1}$ ) considering the following approaches (see methods): the simultaneous approach (SA), showing mean correlations (weakest/strongest); the mean approach (MA); and the variability approach (VA). Six samples were simultaneously carried out in all reservoirs, so SA values are based on the mean for six correlations. COD = chemical oxygen demand. The highest correlations for each variable are in bold.

\begin{tabular}{lccc|ccc}
\hline & \multicolumn{3}{c}{ Pearson $\boldsymbol{r}$} & \multicolumn{3}{c}{ Spearman $\boldsymbol{\rho}$} \\
\hline Environmental variables & SA & MA & VA & SA & MA & VA \\
\hline Ammonium (mg.L $\left.{ }^{-1}\right)$ & $-0.08(-0.13 / 0.68)$ & $\mathbf{- 0 . 2 7}$ & $\mathbf{- 0 . 2 7}$ & $\mathbf{0 . 1 3}(0.01 / 0.39)$ & 0.06 & -0.09 \\
COD (mg.L $\left.{ }^{-1}\right)$ & $\mathbf{0 . 6 5}(0.28 / 0.94)$ & 0.47 & 0.24 & $0.38(0.07 / 0.49)$ & $\mathbf{0 . 6 1}$ & 0.36 \\
Dissolved oxygen (\%) & $-0.36(0.15 /-0.81)$ & $\mathbf{- 0 . 6 6}$ & -0.54 & $-0.25(0.16 /-0.64)$ & $\mathbf{- 0 . 5 0}$ & -0.33 \\
Nitrate (mg.L $\left.{ }^{-1}\right)$ & $\mathbf{- 0 . 3 6}(-0.27 /-0.47)$ & $\mathbf{- 0 . 3 6}$ & -0.19 & $-0.52(-0.16 /-0.78)$ & -0.64 & $\mathbf{- 0 . 6 7}$ \\
Nitrite (mg.L $\left.{ }^{-1}\right)$ & $-0.23(-0.10 /-0.35)$ & $\mathbf{- 0 . 3 9}$ & -0.16 & $-0.22(0.12 /-0.75)$ & -0.57 & $\mathbf{- 0 . 6 6}$ \\
Transparency (m) & $-0.48(-0.32 /-0.64)$ & $\mathbf{- 0 . 5 9}$ & -0.32 & $-0.40(-0.06 /-0.67)$ & $\mathbf{- 0 . 6 6}$ & -0.61 \\
Total phosphorus (mg.L $\left.{ }^{-1}\right)$ & $0.41(0.05 / 0.77)$ & 0.71 & $\mathbf{0 . 7 4}$ & $0.35(0.22 / 0.51)$ & $\mathbf{0 . 5 5}$ & 0.35 \\
\hline
\end{tabular}


ALAGADOS SAMPLING

Correlations for data simultaneously sampled were only observed between: total cyanobacterial abundance and depth, $\mathrm{pH}$ and DO; Aphanizomenon abundance and temperature, $\mathrm{pH}$, total phosphorus and COD; Cylindrospermopsis abundance and depth, pH and DO; Dolichospermum abundance and temperature (Table III).

In turn, stronger and numerous coefficients were observed when using time lag correlations. Correlations werefound between: total cyanobacterial abundance and depth, temperature, $\mathrm{pH}$, nitrate, and dissolved oxygen; Aphanizomenon abundance and depth, temperature, $\mathrm{pH}$, conductivity, and nitrate; Cylindrospermopsis abundance and depth, temperature, $\mathrm{pH}$, total phosphorus, nitrate, and COD; and Dolichospermum and depth, temperature, $\mathrm{pH}$, and total phosphorus (Table III).

\section{DISCUSSION}

IAP SAMPLING

The role of phosphorus in cyanobacterial blooms is particularly clear. Phosphorus concentrations have being considered one of the main drivers

TABLE III

Pearson and Spearman correlation coefficients between environmental variables and cyanobacterial density (cell.mL ${ }^{-1}$ ) considering the simultaneous correlation (SC) and "time lag" correlation (TL) (see methods, highest values are in bold for each comparison). $\mathrm{COD}=$ chemical oxygen demand, $\mathrm{BOD}=$ biochemical oxygen demand, $\mathrm{SRP}=$ soluble reactive phosphorus.

\begin{tabular}{|c|c|c|c|c|c|c|c|c|}
\hline \multirow[b]{3}{*}{ Environmental variable } & \multicolumn{4}{|c|}{ Total cyanobacteria } & \multicolumn{4}{|c|}{ Aphanizomenon } \\
\hline & \multicolumn{2}{|c|}{ Pearson } & \multicolumn{2}{|c|}{ Spearman } & \multicolumn{2}{|c|}{ Pearson } & \multicolumn{2}{|c|}{ Spearman } \\
\hline & $\mathrm{SC}$ & $\mathrm{TL}$ & $\mathrm{SC}$ & $\mathrm{TL}$ & $\mathrm{SC}$ & $\mathrm{TL}$ & $\mathrm{SC}$ & TL \\
\hline Depth (m) & 0.04 & -0.07 & -0.34 & -0.41 & 0.00 & -0.07 & -0.26 & -0.43 \\
\hline Temperature $\left({ }^{\circ} \mathrm{C}\right)$ & 0.31 & 0.39 & 0.28 & 0.49 & 0.34 & 0.41 & 0.31 & 0.49 \\
\hline $\mathrm{pH}$ & 0.40 & 0.44 & 0.40 & 0.38 & 0.34 & 0.43 & 0.39 & 0.40 \\
\hline Turbidity (NTU) & 0.18 & 0.17 & 0.32 & -0.14 & -0.08 & 0.07 & -0.00 & 0.03 \\
\hline Conductivity $\left(\mu \mathrm{S} . \mathrm{cm}^{-1}\right)$ & 0.14 & 0.15 & 0.11 & 0.34 & -0.22 & 0.10 & -0.20 & 0.27 \\
\hline Total phosphorus (mg.L $\left.{ }^{-1}\right)$ & 0.07 & 0.26 & -0.19 & -0.29 & -0.12 & 0.14 & -0.34 & -0.21 \\
\hline $\mathrm{SRP}\left(\mathrm{mg} \cdot \mathrm{L}^{-1}\right)$ & 0.10 & -0.08 & 0.27 & -0.19 & -0.08 & -0.08 & -0.12 & -0.15 \\
\hline Ammonium (mg. $\left.\mathrm{L}^{-1}\right)$ & 0.13 & 0.24 & 0.14 & 0.07 & -0.07 & 0.09 & 0.02 & -0.06 \\
\hline Nitrite $\left(\mathrm{mg} \cdot \mathrm{L}^{-1}\right)$ & -0.21 & -0.09 & -0.19 & -0.14 & -0.10 & -0.00 & 0.04 & 0.05 \\
\hline Nitrate $\left(\mathrm{mg} \cdot \mathrm{L}^{-1}\right)$ & 0.10 & 0.30 & -0.19 & -0.00 & 0.24 & 0.49 & 0.02 & 0.12 \\
\hline Dissolved oxygen $\left(\mathrm{mg} . \mathrm{L}^{-1}\right)$ & 0.41 & 0.27 & 0.33 & 0.12 & 0.14 & 0.17 & 0.06 & -0.00 \\
\hline $\mathrm{COD}\left(\mathrm{mg} \cdot \mathrm{L}^{-1}\right)$ & -0.02 & -0.03 & 0.06 & 0.27 & 0.12 & 0.06 & 0.32 & 0.34 \\
\hline \multirow[t]{2}{*}{ BOD $\left(\mathrm{mg} . \mathrm{L}^{-1}\right)$} & -0.14 & -0.07 & -0.08 & -0.12 & 0.01 & 0.04 & 0.12 & -0.01 \\
\hline & \multicolumn{4}{|c|}{ Cylindrospermopsis } & \multicolumn{4}{|c|}{ Dolichospermum } \\
\hline Depth (m) & 0.03 & -0.11 & -0.36 & -0.39 & -0.04 & -0.02 & -0.24 & -0.13 \\
\hline Temperature $\left({ }^{\circ} \mathrm{C}\right)$ & 0.23 & 0.29 & 0.30 & 0.45 & 0.18 & 0.24 & 0.48 & 0.66 \\
\hline $\mathrm{pH}$ & 0.41 & 0.38 & 0.47 & 0.40 & 0.21 & 0.36 & 0.22 & 0.29 \\
\hline Turbidity (NTU) & 0.20 & 0.24 & 0.28 & -0.02 & 0.22 & 0.31 & -0.03 & -0.32 \\
\hline Conductivity $\left(\mu \mathrm{S} . \mathrm{cm}^{-1}\right)$ & 0.04 & 0.06 & 0.06 & 0.32 & -0.01 & 0.05 & -0.13 & 0.09 \\
\hline Total phosphorus (mg.L $\left.{ }^{-1}\right)$ & 0.11 & 0.46 & -0.20 & -0.19 & 0.14 & 0.46 & -0.13 & -0.16 \\
\hline $\mathrm{SRP}\left(\mathrm{mg} \cdot \mathrm{L}^{-1}\right)$ & 0.12 & -0.05 & 0.31 & -0.11 & 0.14 & -0.01 & 0.03 & -0.18 \\
\hline Ammonium (mg. $\left.\mathrm{L}^{-1}\right)$ & -0.00 & 0.05 & -0.01 & 0.04 & -0.03 & -0.02 & -0.17 & -0.21 \\
\hline Nitrite $\left(\mathrm{mg} \cdot \mathrm{L}^{-1}\right)$ & -0.27 & -0.12 & -0.28 & -0.16 & -0.15 & -0.12 & -0.18 & -0.06 \\
\hline Nitrate $\left(\mathrm{mg} \cdot \mathrm{L}^{-1}\right)$ & 0.22 & 0.51 & -0.04 & 0.06 & 0.09 & 0.11 & 0.13 & 0.18 \\
\hline Dissolved oxygen $\left(\mathrm{mg} \cdot \mathrm{L}^{-1}\right)$ & 0.37 & 0.30 & 0.37 & 0.16 & 0.11 & 0.21 & -0.08 & -0.06 \\
\hline COD (mg. $\left.\mathrm{L}^{-1}\right)$ & -0.01 & 0.08 & 0.08 & 0.24 & 0.04 & 0.04 & 0.31 & 0.45 \\
\hline BOD $\left(\mathrm{mg} \cdot \mathrm{L}^{-1}\right)$ & -0.08 & -0.05 & -0.01 & -0.15 & 0.06 & 0.01 & 0.23 & 0.33 \\
\hline
\end{tabular}


of cyanobacterial growth (Moisander et al. 2003, Tanaka et al. 2004, Nausch et al. 2008, Posselt et al. 2009, Rangel et al. 2012). We have reached this 'highly recurrent' conclusion mainly by analyzing the variability of sampling points (i.e. MA and VA). Our results suggest that the influence of abiotic variables on cyanobacteria, which is recurrently demonstrated in experimental studies, is evidenced only if the variation of the environment is represented in monitoring studies. Correlating snapshot samples in LTPS are clearly insufficient to represent how a certain location is compared to others, resulting in weak cyanobacteria-environment relationships.

The negative relationships between cyanobacteria and nitrogen (mainly observed in MA and SA) can be explained by the fact that some cyanobacteria (Nostocales order) are able to exploit molecular nitrogen when sources of inorganic-N are depleted (Herrero et al. 2001). In high nitrogen concentrations, nostocales cyanobacteria may be outcompeted by other algae that use this limited nutrient. Among the available nitrogen ions, ammonium is an important determinant of cyanobacterial growth (Domingues et al. 2011). However, ammonium showed the weakest correlation with cyanobacterial density in the studied reservoirs. The low stability of this ion may explain the lack of strong relationships. This can also explain why the relationship between ammonium and cyanobacterial abundance is sometimes positive and sometimes negative considering SA.

The negative correlation between cyanobacterial density and transparency is probably a consequence, not a cause, of cyanobacterial growth. The reservoirs located in Paraná are typically dominated by Microcystis aeruginosa (Kützing) Kützing (IAP 2009), which form a scum on the water surface, decreasing underwater radiation available to other phytoplankton groups. This is an important competitive advantage of cyanobacteria. Considering the correlations with other environmental variables, COD represents the amount of dissolved organic matter in the water and has been used as an indicator of environmental pollution in many countries (Zhao et al. 2004). Relatedly, previous studies have also shown that cyanobacteria may vary depending on COD concentrations (Wei et al. 2001, Amé et al. 2003). This was the only variable for which SA showed the strongest Pearson correlation among the three approaches. Dissolved oxygen can vary according to temperature, presence of pollutants, photosynthetic activity, and other reasons (Smith and Bella 1973). This can also explain the variation in correlation values when using SA. Oxygen concentrations were positively or negatively correlated with cyanobacterial abundance, depending on the sampling period.

It is interesting to note that Pearson and Spearman correlations may generate different outputs. Our focus was not to choose the best analysis for each variable considering its distribution. Both Pearson and Spearman correlations are commonly used to evaluate relationships between cyanobacteria and environmental variables (e.g. Bouvy et al. 1999, Rinta-Kanto et al. 2009, Leigh et al. 2010, Conradie and Barnard 2012, Xie et al. 2012). Spearman coefficients were stronger for some variables and weaker for others, indicating that some variables have linear relationships with cyanobacteria while others are non-linear.

Furthermore, correlating environmental variables and cyanobacteria abundance give us only a clue for cyanobacteria determinants, considering that a correlation does not mean causality. However, numerous experimental studies have demonstrated the importance of most environmental variables used here as predictors of cyanobacterial growth (Paerl et al. 1985, Coles and Jones 2000, Aubriot and Bonilla 2012), and conclusions based on correlations are commonly used for cyanobacteria management (Izydorczyk et al. 2008, Rinta-Kanto et al. 2009, Lu et al. 2013). Therefore, identifying the best approach to reveal determinants of cyanobacteria in LTPS monitoring are crucial. 
AlagAdos SAMPLING

Compared to correlations using data simultaneously sampled, stronger and numerous correlations were found in time lag correlations between cyanobacterial abundance and environmental variables. Particularly, the recurrent relationships between cyanobacteria and temperature (Paerl and Huisman 2008) and phosphorus (Isvánovics et al. 2000, Aubriot et al. 2010) were better revealed through the time lag correlations. Therefore, our results highlight that cyanobacteria abundance is promoted by environmental conditions that acted previously at the site, and reliable relationships (indicating possible causal relations) are revealed only using time lag samplings.

Surely, the best strategy to identify cyanobacterial determinants in observational studies is to continuously sample environmental variables and cyanobacterial abundance to track for short-term responses. However, such strategy is rarely applied by monitoring agencies, probably due to logistic and financial restrictions. Instead, monitoring studies usually carry out periodic snapshot samplings to reveal cyanobacteria determinants. We argue that, at least for traditional cyanobacteria monitoring, the SA for correlating environmental variables and cyanobacterial abundance may not reveal the determinants of cyanobacteria in reservoirs.

We advocate that investigating the temporal variation of sampling points (i.e. MA and VA) may provide conclusive answers regarding the relationship between environmental variables and cyanobacteria. We conclude that environmental variables sampled synchronously with cyanobacteria are worse predictors of the population density of these microalgae than metrics that represent temporal variation in habitats in long-term monitoring studies.

\section{ACKNOWLEDGMENTS}

We are grateful to "Instituto Ambiental do Paraná" and "SANEPAR" for providing the data necessary for this study. We acknowledge Coordenação de
Aperfeiçoamento de Pessoal de Nível Superior (CAPES) and Conselho Nacional de Desenvolvimento Científico e Tecnológico $(\mathrm{CNPq})$ for continuous financial support. J.W. received a $\mathrm{PhD}$ scholarship from CAPES. We would also like to thank Dr. Jeffrey D. Muehlbauer for an extensive English review. We also acknowledge Dr. João C. Nabout and other anonymous reviewers for their valuable suggestions to a previous draft of the manuscript.

\section{RESUMO}

Um dos principais objetivos de monitorar as florações de cianobactérias em ambientes aquáticos é revelar a relação entre a abundância de cianobactérias e as variáveis ambientais. Esses estudos tipicamente correlacionam dados coletados simultaneamente. No entanto, as amostragens ocorrem esparsamente ao longo do tempo e não são capazes de revelar respostas de curto prazo na abundância de cianobactérias frente às mudanças ambientais. Neste estudo, testamos a hipótese de que relações mais fortes entre cianobactérias e variáveis ambientais no monitoramento de cianobactérias são encontradas quando a variabilidade temporal dos pontos de amostragem é incorporada nas análises estatísticas. Para isso, nós investigamos as relações entre cianobactérias e sete variáveis ambientais que foram amostradas duas vezes por ano, durante três anos, em 11 reservatórios, e dados de um monitoramento intensivo em um desses reservatórios. Relações fracas foram encontradas correlacionando dados coletados simultaneamente. De fato, o papel "altamente recorrente" do fósforo nas florações de cianobactérias não foi devidamente observado em todos os períodos de amostragem. Por outro lado, coeficientes de correlação mais fortes entre fósforo total e cianobactérias foram observados quando usamos a variabilidade dos pontos de amostragem. Nós também mostramos que as variáveis ambientais explicam melhor a densidade de cianobactérias quando um atraso é considerado. Nós concluímos que, no monitoramento de cianobactérias, a melhor abordagem para revelar os determinantes das florações de cianobactérias é considerar a variabilidade ambiental. 
Palavras-chave: algas nocivas, reservatório, gestão, variáveis limnológicas, variação temporal, Neotropical.

\section{REFERENCES}

AMÉ MV, DíAZ M AND WunderLin DA. 2003. Occurrence of toxic cyanobacterial blooms in San Roque Reservoir (Córdoba, Argentina): A field and chemometric study. Environ Toxicol 18: 192-201.

ANDREOLI CV AND CARNEIRO C. 2005. Gestão integrada de mananciais de abastecimento eutrofizados. Curitiba: Companhia de Saneamento do Paraná SANEPAR/ FINEP, $494 \mathrm{p}$.

AUBRIOT L AND BONILla S. 2012. Rapid regulation of phosphate uptake in freshwater cyanobacterial blooms. Aquat Microb Ecol 67: 251-263.

Aubriot L, WAGNer F AND FALKNER G. 2010. The phosphate uptake behaviour of phytoplankton communities in eutrophic lakes reflects alterations in the phosphate supply. Eur J Phycol 35: 255-262.

AZEVEDO SMFO, CARMICHAEL WW, JOCHIMSEN EM, RINEHART KL, LAU S, SAHW GR AND EAGLESHAM GK. 2002. Human intoxications by microcytins during renal dialysis treatment in Caruaru - Brazil. Toxicology 181: 441-446.

BitTENCOURT-OliveIRAMC, DiAs SN, MOURANA, CORDEIROARAÚJO MK AND DANTAS EW. 2012. Seasonal dynamics of cyanobacteria in a eutrophic reservoir (Arcoverde) in a semi-arid region of Brazil. Braz J Biol 72: 533-544.

BOUVy M, FAlCÃo D, MARINHO M, PAGANO M AND MOURAA. 2000. Occurrence of Cylindrospermopsis (cyanobacteria) in 39 Brazilian tropical reservoirs during the 1998 drought. Aquat Microb Ecol 23: 13-27.

Bouvy M, MOLICA R, Oliveira S, MARINHO M AND BeKer B. 1999. Dynamics of a toxic cyanobacterial Bloom (Cylindrospermopsis raciborskii) in a shallow reservoir in the semi-arid region of northeast Brazil. Aquat Microb Ecol 20: 285-297.

Burford MA, JOHNSON SA, COOK AJ, PACKER TV, TAYLOR BM AND TOWNSLEY ER. 2007. Correlations between watershed and reservoir characteristics, and algal blooms in subtropical reservoirs. Water Res 41: 4105-4114.

CHORUS I AND BARTRAM J. 1999. Toxic cyanobacteria in water: a guide to their public health consequences, monitoring and management. London: E \& FN SPON, 416 p.

COLES JF AND JONES RC. 2000. Effect of temperature on photosynthesis-light response and growth of four phytoplankton species isolated from a tidal freshwater river. J Phycol 36: 7-16.

CONRADIE KR AND BARNARD S. 2012. The dynamics of toxic Microcystis strains and microcystin production in two hypertrofic South African reservoirs. Harmful Algae 20: 1-10.

Dantas EW, Moura AN And BitTencourt-Oliveira MC. 2011. Cyanobacterial blooms in stratified and destratified eutrophic reservoirs in semi-arid region of Brazil. An Acad Bras Cienc 83: 1327-1338.
DOMINGUES RB, BARBOSA AB, SOMMER U AND GALVÃo HM. 2011. Ammonium, nitrate and phytoplankton interactions in a freshwater tidal estuarine zone: potential effects of cultural eutrophication. Aquat Sci 73: 331-343.

FERnANDES LF, Gutseit KC, WoJCIECHOWSKi J, LAgos PED, XAVIER CF AND Wosiack AC. 2011. Ecologia do fitoplâncton no reservatório Rio Verde. In: Cunha CLN, Carneiro C, Gobbi EF and Andreoli CV (Eds), Eutrofização em Reservatórios: Gestão Preventiva. Estudo Interdisciplinar na Bacia do Rio Verde, PR. Curitiba: Ed. da UFPR, p. 286-306.

Fernandes LF, Wosiack AC, Domingues L, Pacheco CV AND LAGOS PED. 2005. Cianobactérias e cianotoxinas. In: Andreoli CV and Carneiro C (Eds), Gestão integrada de mananciais de abastecimento eutrofizados. Curitiba: Sanepar-Finep, p. 369-388.

Gomes LNL, OLIVEIRA SMAC, GIANI A AND VON SPERLING E. 2012. Association between biotic and abiotic parameters and the occurrence of cyanobacteria in a Brazilian reservoir. Environ Monit Assess 184: 4635-4645.

Havens KE, Phlips EJ, Cichra MF AND Li B. 1998. Light availability as a possible regulator of cyanobacteria species in a shallow subtropical lake. Freshwater Biol 39: 547-556.

Herrero A, Muro-PAStor AM AND Flores E. 2001. Nitrogen control in Cyanobacteria. J Bacteriol 183: 411-425.

Huisman J, MatThiJs HCP AND Visser PM. 2005. Harmful Cyanobacteria. Netherlands: Springer, 241 p.

Huszar VLM, Silva LHS, Marinho M, DOMINGOS P AND SANT'ANNA CL. 2000. Cyanoprokaryote assemblages in eight productive tropical Brazilian waters. Hydrobiologia 424: 67-77.

IAP-INSTITUTO AMBIENTALDOPARANÁ. 2009. Monitoramento da qualidade das águas dos reservatórios do Estado do Paraná, no período de 2005 a 2008. Curitiba. Available in: www.iap.pr.gov.br, 120 p.

ISVÁNOVICS V, SHAFIK HM, PRÉSING M AND JUHOS S. 2000. Growth and phosphate uptake kinetics of the cyanobacterium, Cylindrospermopsis raciborskii (Cyanophyceae) in throughflow cultures. Freshwater Biol 43: 257-275.

IZYDORCZYK K, JURCZAK T, WOJTAL-FRANKIEWICZ A, SKOWRON A, MANKIEWICZ-BOCZEK J AND TARCZYNSKA M. 2008. Influence of abiotic and biotic factors on microcystin content in Microcystis aeruginosa cells in a eutrophic temperate reservoir. J Plankton Res 30: 393-400.

LeIGH C, Burford MA, Roberts DT AND Udy JW. 2010. Predicting the vulnerability of reservoirs to poor water quality and cyanobacterial blooms. Water Res 44: 44874496.

Lu X, Tian C, Pei H, Hu W and Xie J. 2013. Environmental factors influencing cyanobacteria community structure in Dongping Lake, China. J Environ Sci 25: 2196-2206.

MCBRIDE GB. 2005. Using Statistical Methods for Water Quality Management: Issues, Problems and Solutions. New Jersey: J Wiley \& Sons, 344 p. 
Moisander PH, Steppe TF, Hall NS, Kuparinen J AND PAERL HW. 2003. Variability in nitrogen and phosphorus limitation for Baltic Sea phytoplankton during nitrogenfixing cyanobacterial blooms. Mar Ecol-Prog Ser 262: 81-95.

MOURA AN, DANTAS EW, OliveIRA HSB AND BITTENCOURTOLIVEIRA MC. 2011. Vertical and temporal dynamics of cyanobacteria in the Carpina potable water reservoir in northeastern Brazil. Braz J Biol 71: 451-459.

NAUSCh M, NAUSCH G, WASMUnd N AND NAgEL K. 2008. Phosphorus pool variations and their relation to cyanobacteria development in the Baltic Sea: A three-year study. J Marine Syst 71: 99-111.

Oliveira FHPC, CAPEla E, Ara ALS, Moreira CHP, LIRA OO, PADILHA MRF AND SHINOHARA NKS. 2014. Seasonal changes of water quality in a tropical shallow and eutrophic reservoir in the metropolitan region of Recife (Pernambuco-Brazil). An Acad Bras Cienc 86: 1863-1872.

PAERL HW, BLAND PT, BOWles ND AND HAIBACH ME. 1985. Adaptation to High-Intensity, Low-Wavelength Light among Surface Blooms of the Cyanobacterium Microcystis aeruginosa. Appl Environ Microb 49: 1046-1052.

PAERL HW AND HUISMAN J. 2008. Blooms Like It Hot. Science 320: 57-58.

PAERL HW AND Huisman J. 2009. Climate change: a catalyst for global expansion of harmful cyanobacterial blooms. Environ Microbiol Rep 1: 27-37.

Posselt AJ, Burford MA AND Shaw G. 2009. Pulses of phosphate promote dominance of the toxic cyanophyte Cylindrospermopsis raciborskii in a subtropical water reservoir. J Phycol 45: 540-546.

QUESADA A AND FERNÁNDEZ-VALIENTE E. 1996. Relationship between abundance of $\mathrm{N}_{2}$-fixing cyanobacteria and environmental features of Spanish rice fields. Microbial Ecol 32: 59-71.

RANGEL LM, SILVA LHS, ROSA P, ROLAND F AND HUSZAR VLM. 2012. Phytoplankton biomass is mainly controlled by hydrology and phosphorus concentrations in tropical hydroelectric reservoirs. Hydrobiologia 693: 13-28.
RINTA-KANTO JM, KONOPKO EA, DEBRUYN JM, BOURBONNIERE RA, BOYER GL AND WILHELM SW. 2009 Lake Erie Microcystis: Relationship between microcystin production, dynamics of genotypes and environmental parameters in a large Lake. Harmful Algae 8: 665-673.

SMith SA AND BELlA DA. 1973. Dissolved Oxygen and Temperature in a Stratified Lake. J Water Pollut Control Fed 45: 119-133.

STATSOFT, INC. 2005. STATISTICA (data analysis software system), version 7.1. www.statsoft.com.

TANAKA T, RASSOUlzadEGAN $F$ AND THINGSTAD TF 2004. Orthophosphate uptake by heterotrophic bacteria, cyanobacteria, and autotrophic nanoflagellates in Villefranche Bay, northwestern Mediterranean: Vertical, seasonal, and short-term variations of the competitive relationship for phosphorus. Limnol Oceanogr 49: 1063-1072.

VEZIE C, BRIENT L, SiVONEN K, BERTRU G, LEFEUVRE JC AND SALKINOJA-SALONEN M. 1998. Variation of microcystin content of cyanobacterial blooms and isolated strains in Lake Grand-Lieu (France). Microbial Ecol 35: 126-135.

Wei B, Sugiura N AND MaEKaWA T. 2001. Use of artificial neural network in the prediction of algal blooms. Water Res 35: 2022-2028.

WiCKS RJ AND THIEL PG. 1990. Environmental factors affecting the production of peptide toxins in floating scums of the cyanobacterium Microcystis aeruginosa in a hypertrophic african reservoir. Environ Sci Technol 24: 1413-1418.

XIE L, Rediske RR, Hong Y, O'KeEFe J, GILlett ND, Dyble J AND STEINMAN AD. 2012. The role of environmental parameters in the structure of phytoplankton assemblages and cyanobacteria toxins in two hypereutrophic lakes. Hydrobiologia 691: 255-268.

Yoo RS, CARMICHEL WW, HoEHN RC AND HRUdEY SE. 1995. Cyanobacterial (Blue-Green Algal) Toxins: A Resource Guide. AWWA Research Foundation and American Water Works Association, 229 p.

ZHAO H, JiANG D, ZHANG S, CATTERALL K AND JOHN R. 2004. Development of a direct photoelectrochemical method for determination of chemical oxygen demand. Anal Chem 76: $155-160$. 